\title{
Improvement of Power Quality WECS using AI Based STATCOM
}

\section{A Ayyappa Swamy ${ }^{1}$ | P Ankineedu Prasad ${ }^{2}$}

${ }^{1}$ PG Student, Dept of EEE, Vikas Group of Institutions, Vijayawada, India

${ }^{2}$ Associate Professor, Dept of EEE, Vikas Group of Institutions, Vijayawada, India

\section{To Cite this Article}

A Ayyappa Swamy and P Ankineedu Prasad, "Improvement of Power Quality WECS using AI Based STATCOM", International Journal for Modern Trends in Science and Technology, 6(8): 5-9, 2020.

\section{Article Info}

Received on 22-May-2020, Revised on 22-June-2020, Accepted on 25-July-2020, Published on 27-July-2020.

\section{ABSTRACT}

The major concern in a growing power quality is harmonics distortion which is caused by the non-linear nature of the loads. This problem has drawn much attention from utilities, users and industries. To reduce the harmonic distortion for improving the power quality of the system a custom power devices has been proposed. A static compensator (STATCOM) is implemented at distribution level for overcoming several power quality problems. In this paper, new control technic i.e AI is proposed on shunt compensator to estimates the weight values of load currents. The control approach is based on the convergence of the load currents and property of the input signal. A working prototype of the STATCOM is implemented using three-phase VSC and AI control technique based PWM controller approach is developed in MATLAB/SIMULINK.

Index Terms-WECS, AI Technique, Power Quality, THD, STATCOM and VSC

\section{INTRODUCTION}

Generally, with increase in the power demand due to increase in population, utilization, the Generation of power was really a challenge now a day. Due to high utilization of non-conventional energy sources [1] as a one of the distribution energy source, may causes the stability problems such as voltage regulation and other power quality problems. Therefore, the power electronic based forced commutated converters are preferred in distribution system for maintaining the system stability, reliable performance and efficient work and also improving the quality of power at coupling junction point.

The current distortions in non-linear load may result same distortions in the system voltages and in some cases also shows the serious effect on power system. Generally, the problems in power system are more complicated and also have difficult to identify the problem when we integrate the wind energy system with grid connection [2]. If this problems continuous, it's mainly causes the damage

of system and also reduces the system efficiency. By controlling the system parameters such as magnitude of voltage, transmission impedance and load angle then we maintain the power flow. The power flow controlling device is a device which is used for varying and controlling the system parameters [3].

A shunt device is a compensating device i.e. which is connected between the grid connected point called as PCC and the ground [4]. Shunt device either can absorb or generate the reactive power for controlling the magnitude of voltage at point of common coupling. 
The reactive power compensation is also one of the application of shunt converter devices [5]. Figure 1 shows the basic diagram for the shunt connected inverter based grid connected system [6].

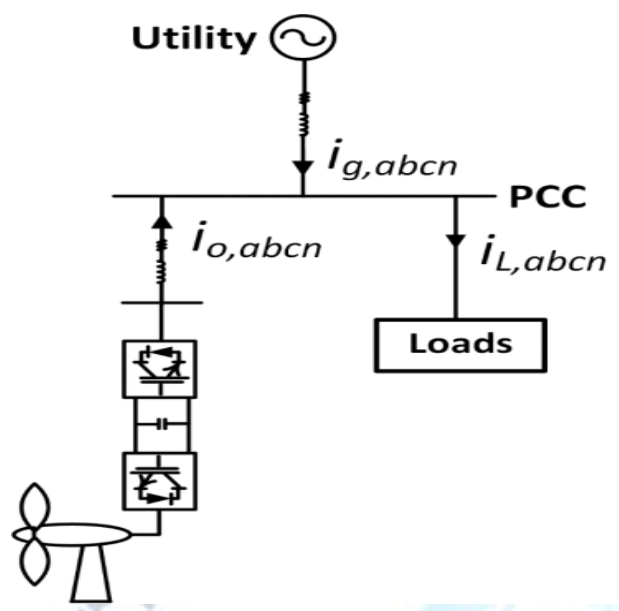

Figure 1: Diagram for Proposed System.

\section{GRID INTERCONNECTION OF WIND ENERGY SYSTEM}

Recently grid connected wind system have been spreading in residential areas and in industrial areas. So we have to find a suitable MPPT technique that gives a better power output when connected is to find out. For a grid connected system there are certain factors that have been considered such that DC-AC conversion with highest output power quality with the proper design of filters System main controlling factors like MPPT. Grid interface inverters which transfers the energy from the wind energy generation system to the grid by maintaining constant of dc link voltage. For a grid connected system the utility network mainly demands for better power quality and power output. In the case of voltage fluctuations control of grid parameters is very difficult. So for a wind system that is connected to a grid first stage is the boosting stage and the second stage is DC-AC converter [7]. An output filter is usually employed which reduces the ripple components due to switching problems. The problem associated with the grid connected system is that the dc link voltage that must be oscillates between the two levels which depends on the operating climatic conditions (ambient temperature \& irradiance) in which inverter which acts us a power controller between the dc link and the utility. Dc link is generally used to isolate between the grid side and the inverter side so that we can control both wind system and grid separately. All the available power that can be extracted from the wind system is transferred through the grid [8]-[9].

\subsection{Wind Energy System:}

The generation of electrical power is obtained mainly in two ways i.e one is conventional source and other is non- conventional energy sources. The generation of electricity using non-renewable resources such as coal, natural gas, oil and so on, shows great impact on the environment by production of pollution from their general gases. Hence, by considering all these conditions the generation of electricity is obtained from the renewable energy sources.

Basically, out of all renewable energy sources the wind turbine plays an important role for generating electricity. And also from economical point of view the wind turbine has low maintainece cost because it needs no fuel so that it is pollution free. Mostly, in present world 50-60 percent [13] of energy is generated from wind turbine as compared with all other renewable energy sources.

The typical layout of wind power generation as shown below.

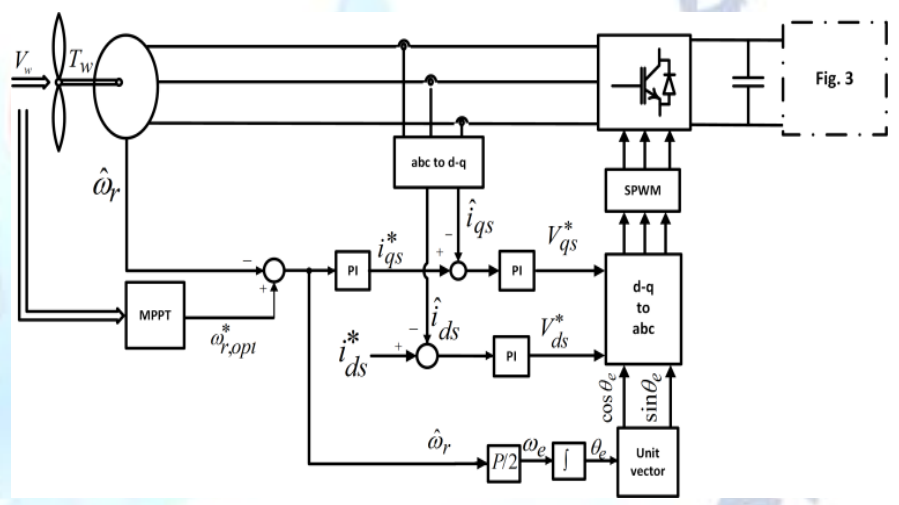

Figure 2: Control scheme of machine side converter The wind turbine converters wind energy to electrical energy and the generator mechanical shaft power is obtained by the following expression:

$$
\mathrm{P}_{\mathrm{m}}=0.5 \rho \mathrm{AC}_{\mathrm{p}} \mathrm{v}^{3}
$$

And the coefficient of power also plays a key role for wind system and the basic minimum value of power coefficient is 0.5 . The power coefficient is obtained by the ratio of tip speed ratio to pitch angle. The pitch angle is the angle to which the blades of turbine is arranged based on their longitude axis and changing of wind direction. The tip speed ration is defined as ratio of linear speed of the rotor to the wind speed.

Fig. 3 shows a typical waveform for coefficient of power with respect to the tip speed ratio. The maximum achievable range of TSR is from 0.4 to 0.5 for turbine with high speed and from 0.2 t0 0.4 for turbine with low speed [14]. 


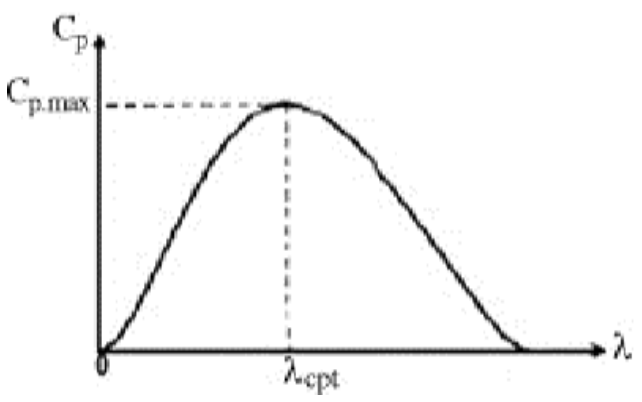

Fig 3: Power coefficient Vs Tip Speed Ratio

\section{STATCOM AND ITS CONTROL Technique}

A STATCOM is built with Thyristors with turn-off capability like GTO or today IGCT or with more and more IGBTs.A STATCOM based control technology has been proposed for improving the power quality which can technically manages the power level associates with the commercial photo voltaic system. The proposed Solar based STATCOM control scheme for grid connected photo voltaic energy generation for power quality improvement has following objectives.

- Unity power factor at the source side.

- Reactive power support only from STATCOM to wind Generator and Load.

- The Dc voltage is obtained for STATCOM is generated from Solar Cells.

A STATCOM is a controlled reactive-power source. The STATCOM is connected to the power system at a PCC (point of common coupling), through a step-up coupling transformer, where the voltage-quality problem is a concern [10]. It provides voltage support by generating or absorbing reactive power at the point of common coupling without the need of large external reactors or capacitor banks. Using the controller, the VSC and the coupling transformer, the STATCOM operation is illustrated in Figure 4.

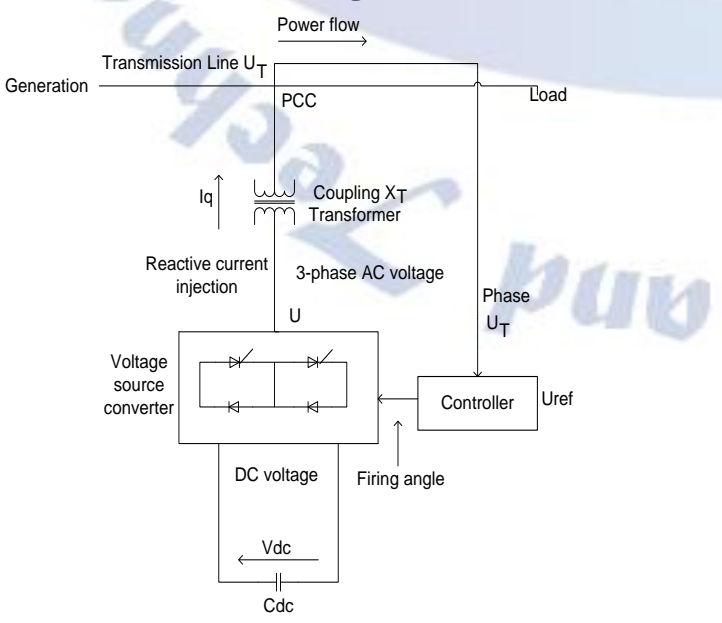

Figure 4: Basic Block Diagram for Static

Compensator
The utilization of different types of electrical loads in three phase system, produces an unbalances in current, which causes the unreliable power. Thereby for maintaining the electrical reliability the statcom controller plays a key role. In this statcom control technique, the reference voltage and dc link capacitor voltages are compared and the result obtained from this is converted to two phase coordinators called as orthogonal vectors.

The STATCOM acts either as a source or a sink of reactive power. It provides voltage support by injecting or by absorbing reactive power at the point of common coupling without any large external reactors or capacitor banks. Here we use a PID controller with STATCOM for damping enhancement. The PID controller is designed using the Model Control Theory. The mathematical modelling of the controller is given in [10]. The control scheme used here is shown in the Figure 5. $\mathrm{Vsm}=\{2 / 3(\mathrm{~V} 2 \mathrm{sa}+\mathrm{V} 2 \mathrm{sb}+\mathrm{V} 2 \mathrm{sc}) 1 / 2\}$

The in-phase unit vectors are obtained from AC source phase voltage and the RMS value of unit vector Usa, Usb, Usc as shown in (b)

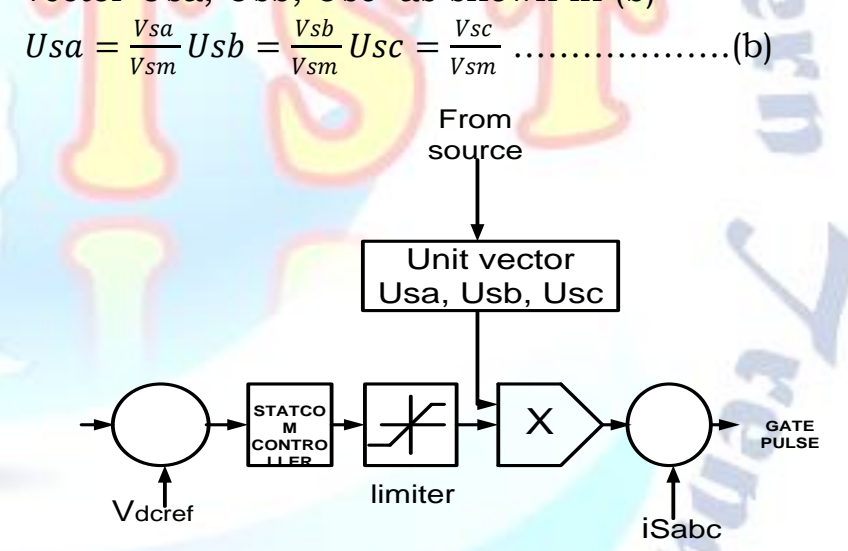

Figure 5: Control Diagram

\section{SIMULATION STUDY}

The proposed control scheme is simulated using SIMULINK in power system block set. The main block diagram of the system operational scheme is shown in Figure. 1. The simulation diagram of the proposed PV cell based grid interfaced system using Statcom is as shown in figure 6. 


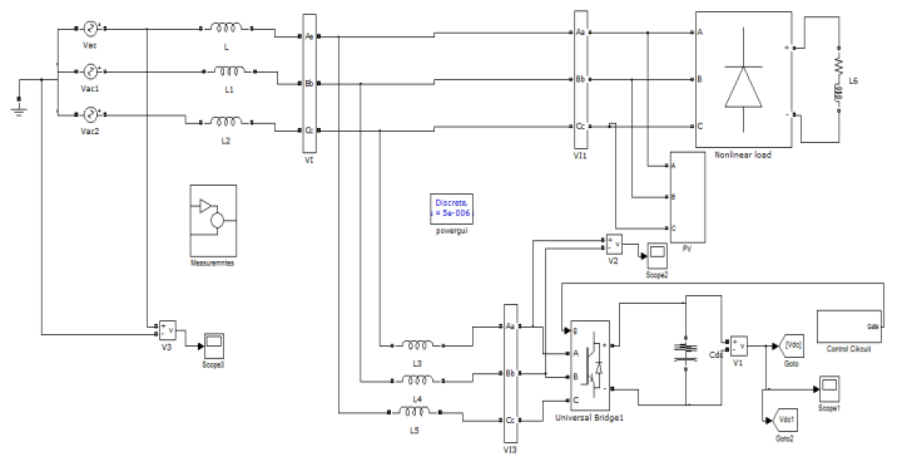

Figure 6: Simulation Diagram of Proposed Grid Connected System

The simulation diagram for proposed WECS based grid interconnected system with STATCOM controller to improve the PQ improvement is shown in figure 6. In this case, the proposed system is tested under controllers namely a) Conventional PI Controller and b) AI Controller.

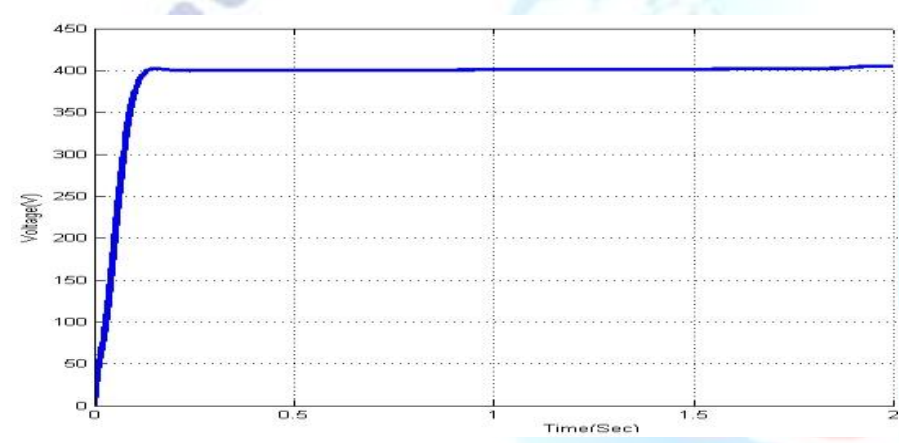

Figure 7: Output voltage of the DC Capacitor system

Output voltage from the DC-Link Capacitor is shown in figure 7 . Here, the input oxidation for fuel cell system is taken at $200 \mathrm{msec}$. and the output voltage from the system is approximately $400 \mathrm{v}$.

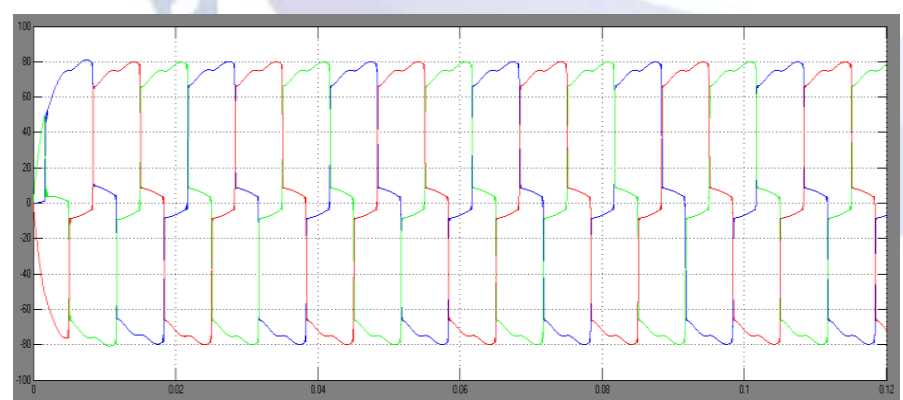

Figure 8: Three phase output currents at load

This proposed system is implemented and applied to three phase non-linear load. The harmonics caused by the non-linear loads are shown in figure 8. To mitigate this harmonic currents an STATCOM controller is proposed in this paper. The injected current from the STATCOM controller is shown in figure 9.

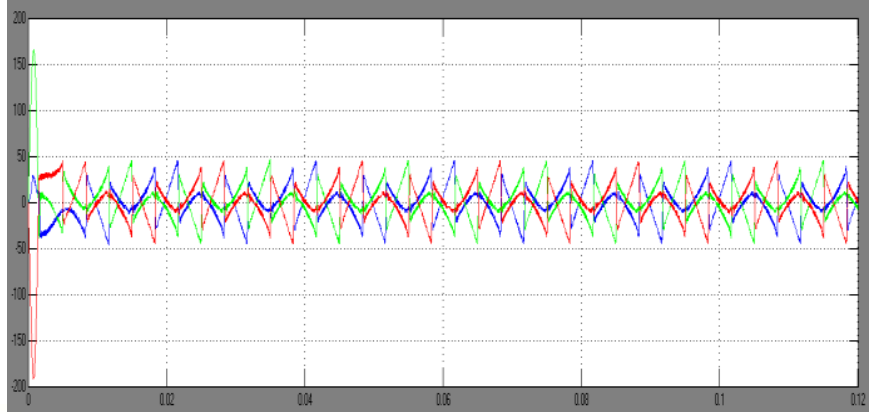

Figure 9: STATCOM injected Current

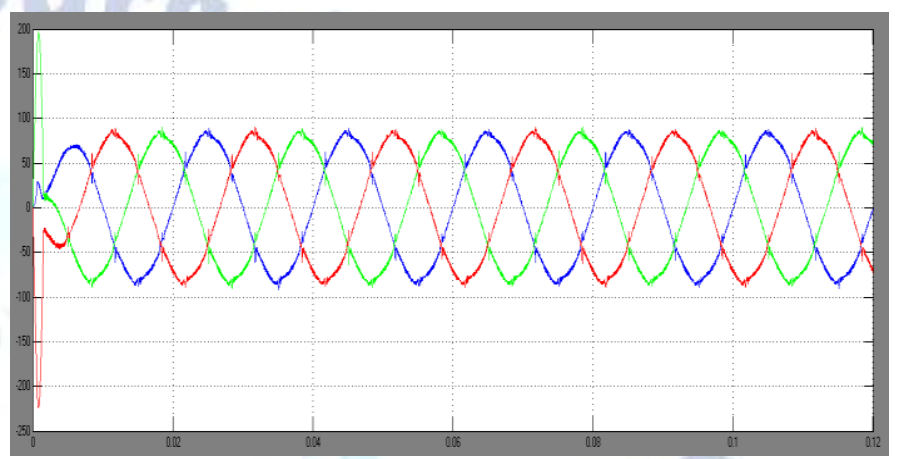

Figure 10: Grid Current after compensation

Figure 10 shows the simulation result for compensated current from shunt controller at grid side. The harmonic distortions in source current is shown in figure 11 and figure 12 with conventional PI and Fuzzy controllers respectively. Figure 13 shows the simulation result for grid current and voltage to show the in-phase compensation (power factor).

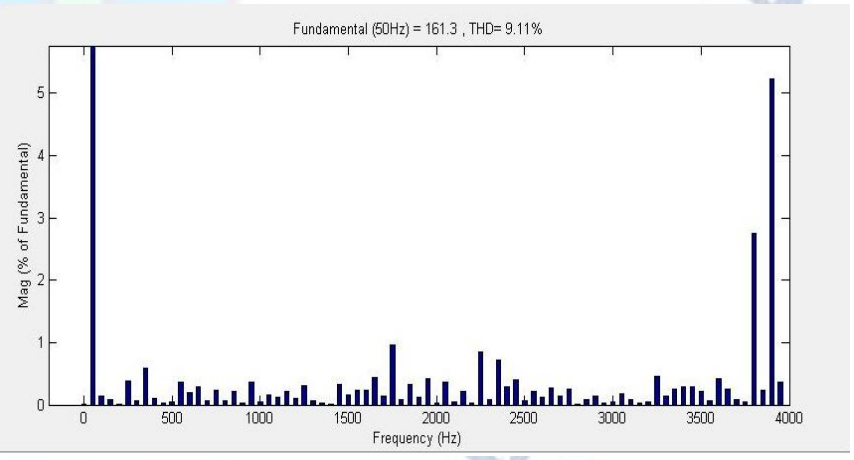

Figure 11: Current harmonic distortion using PI

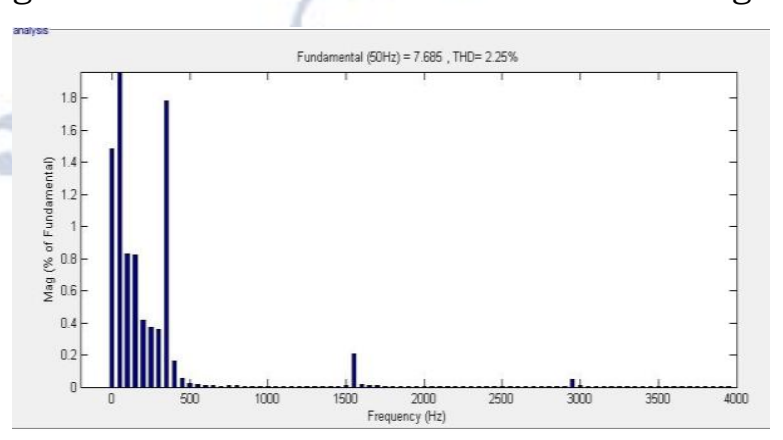

Figure 12: Current harmonic distortion using Fuzzy 


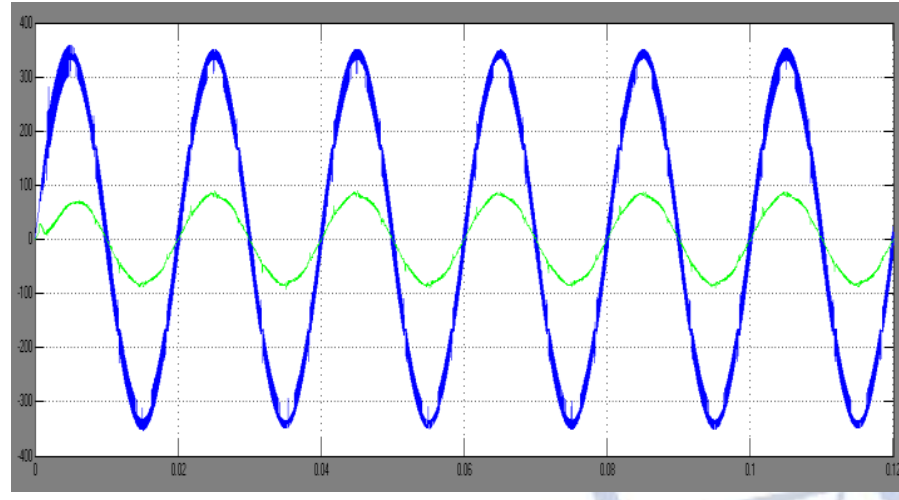

Figure 13: In-phase representation for voltage and current

\section{v. CONCLUSION}

The paper presents the STATCOM based control scheme for power quality improvement in grid connected Wind Energy System with non-linear load. The power quality issues and its consequences on the consumer and electric utility are presented. The operation of the control system developed for the STATCOM in MATLAB/SIMULINK for maintaining the power quality is simulated. It has a capability to cancel out the harmonic parts of the load current. In this paper, the power quality improvement is achieved for given hybrid system with STATCOM controller using PI and AI controllers. The control diagram for shunt active filter is designed with instantaneous active and reactive power controller. With these results, the AI based STATCOM controller for proposed gives better result as compared with conventional controller. The THD under non-linear load with PI controller is $9.11 \%$ while the THD for the same with AI controller is $2.25 \%$.

\section{REFERENCES}

[1] Qing-Chang Zhong, Senior Member, Cascaded Current-Voltage Control to Improve the Power Quality for a Grid-Connected Inverter With a Local Load" in IEEE TRANSACTIONS ON INDUSTRIAL ELECTRONICS, VOL. 60, NO. 4, APRIL 2013

[2] K. S. Hook, Y. Liu, and S. Atcitty, "Mitigation of the wind generation integration related power quality issues by energy storage,” EPQU J., vol. XII, no. 2, 2006.

[3] R. Billinton and Y. Gao, "Energy conversion system models for adequacy assessment of generating systems incorporating wind energy," IEEE Trans. on E. Conv., vol. 23, no. 1, pp. 163-169, 2008, Multistate.

[4] Wind Turbine Generating System-Part 21, International standard-IEC 61400-21, 2001.

[5] J. Manel, "Power electronic system for grid integration of renewable energy source: A survey," IEEE Trans. Ind. Electron., vol. 53, no. 4, pp. 1002-1014, 2006, Carrasco.

[6] M. Tsili and S. Papathanassiou, "A review of grid code technology requirements for wind turbine," Proc. IET Renew.power gen., vol. 3, pp. 308-332, 2009.
[7] S. Heier, Grid Integration of Wind Energy Conversions. Hoboken, NJ: Wiley, 2007, pp. 256-259.

[8] J. J. Gutierrez, J. Ruiz, L. Leturiondo, and A. Lazkano, "Flicker measurement system for wind turbine certification," IEEE Trans. Instrum. Meas., vol. 58, no. 2, pp. 375-382, Feb. 2009.

[9] Indian Wind Grid Code Draft report on, Jul. 2009, pp. 15-18, C-NET.

[10] C. Han, A. Q. Huang, M. Baran, S. Bhattacharya, and W. Litzen berger, "STATCOM impact study on the integration of a large wind farm into a weak loop power system," IEEE Trans. Energy Conv., vol. 23, no. 1, pp. 226-232, Mar. 2008.

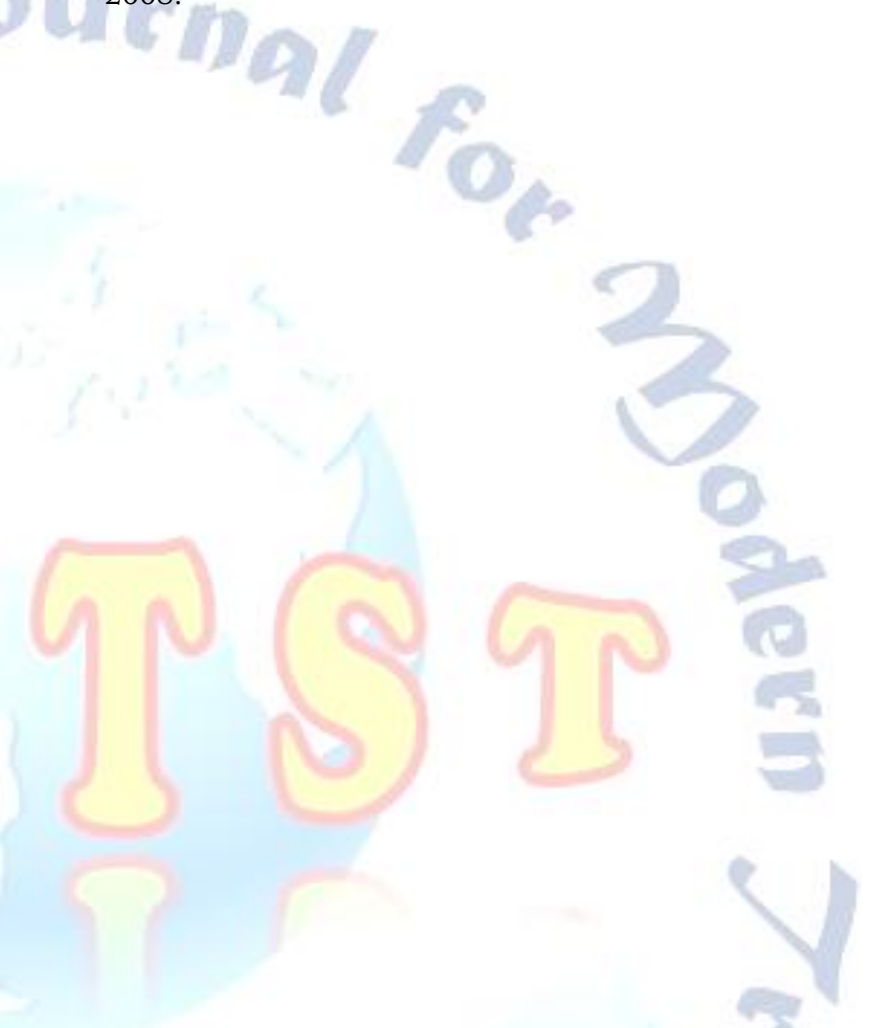

